\title{
ANALISIS KEMAMPUAN ABSTRAKSI MATEMATIS DALAM PEMBELAJARAN MATEMATIKA DI MAN 1 TASIKMALAYA
}

\author{
Muhammad Taufiq Syarifudin ${ }^{1}$, Nani Ratnaningsih ${ }^{2}$, Khomsatun Ni' mah $^{3}$ \\ 1,2, ${ }^{3}$ Magister Pendidikan Matematika, Universitas Siliwangi, Kota Tasikmalaya \\ muhammadtaufiqsyarifudin@gmail.com*1, naniratnaningsih@unsil.ac.id², \\ khomsatunnimah@unsil.ac.id ${ }^{3}$ \\ *Corresponding Author
}

Received 13 February 2021; revised 15 December 2021; accepted 21 December 2021.

\begin{abstract}
ABSTRAK
Tujuan dilakukannya penelitian ini adalah untuk menguraikan kemampuan abstraksi matematis peserta didik dalam mengerjakan soal trigonometri yaitu aturan sinus di kelas 12 MAN 1 Tasikmalaya. Penelitian memakai pendekatan kualitatif yaitu jenis penelitian deskriptif. Subjek penelitian terdiri dari 3 orang yang diambil berdasarkan level kemampuan abstraksi matematis tinggi, sedang, dan rendah. Sebelumnya dilakukan pemeriksaan kesahan data dengan mencocokkan hasil tes dengan hasil wawancara. Hasil penelitian menunjukkan bahwa peserta didik dengan abstraksi tinggi mencapai semua indikator yaitu mentransportasi masalah ke dalam bentuk dan simbol, membuat persamaan yang setara, menyatakan hubungan antara konsep bangun datar dengan trigonometri, menggeneralisasi, membuat persamaan sesuai situasi yang diberikan. Peserta didik dengan abstraksi sedang tidak mampu mencapai 1 indikator yaitu mencari hubungan antara konsep bangun datar dengan trigonometri. Sedangkan peserta didik dengan abstraksi rendah hanya mencapai 1 indikator saja yaitu membuat persamaan yang setara.
\end{abstract}

Kata kunci: daring, kemampuan abstraksi matematis, pembelajaran matematika.

\begin{abstract}
The purpose of this research is to describe the mathematical abstraction ability of students in working on trigonometric questions, namely the rules of the sinus for grade 10 even semester in MAN 1 Tasikmalaya. The research used a qualitative approach, namely a descriptive research type. The research subjects consisted of 3 people who were drawn based on the level of high, medium, and low mathematical abstraction ability. Previously, data validity was checked by matching test results with interview results. The results showed that students with high abstraction achieved all indicators. Students with moderate abstraction are unable to achieve 1 indicator,
\end{abstract}


namely looking for a relationship between the concept of flat shapes and trigonometry. Whereas students with low abstraction only achieved 1 indicator, namely making an equivalent equation.

Keywords: online, mathematical abstraction ability, mathematics learning.

\section{PENDAHULUAN}

Belajar suatu kebutuhan setiap orang. Belajar digambarkan sebagai suatu proses mengubah tingkah laku dalam memperoleh perbaikan terhadap beberapa bentuk sebagai suatu pengalaman (Utami, dkk., 2021). Secara psikologis perubahan tingkah laku tersebut dapat diamati baik dari tutur katanya, motorik maupun gaya hidupnya (Firmansyah \& Ratnaningsih, 2019).

Pembelajaran di sekolah tentunya perlu memberikan arahan kepada peserta didik untuk menumbuhkan kemampuan berpikir diantaranya kemampuan abstraksi matematis. Kemampuan ini merupakan proses yang mendasar dan penting sehingga peserta didik harus memilikinya. Pendidik dianjurkan untuk membangun kemampuan abstraksi matematis pada setiap individu peserta didik yang diharapkan mampu membangun kembali pengetahuan matematika ke dalam sebuah struktur yang baru yang berkaitan dengan masalah sehari-hari (Warsito, dkk., 2020).

Dari rangka konstruktivis, abstraksi dipandang sebagai suatu prosedur dari mulai yang nyata hingga abstrak dengan tingkat perkembangan (Nugroho dkk., 2021). Produk dari proses abstraksi matematis adalah kemampuan abstraksi matematis. Namun, kemampuan matematis peserta didik Indonesia masih condong belum sesuai dengan yang diharapkan (Wibowo, 2018).

Juniarti dan Zulkarnaen (2019) dalam penelitiannya mengemukakan bahwa kemampuan abstraksi matematis peserta didik kelas 10 pada satu SMA Negeri di Karawang masih rendah yang ditunjukkan dengan ketidakmampuan peserta didik dalam mempresentasikan masalah menjadi sebuah model matematis dan memberikan interpretasi terhadap ekspresi matematis. Penelitian sebelumnya pun menemukan hal yang sama bahwa kemampuan abstraksi matematis kelas 10 IPA 1 SMAN 1 Leuwimunding masih perlu ditingkatkan, yaitu peserta didik masih kesulitan dalam menggambarkan objek yang secara konkret tidak nyata 
(Nurhikmayati, 2017). Berdasarkan hal tersebut perlu adanya peninjauan kembali tentang kemampuan abstraksi matematis ini.

Nurhasanah mengungkapkan bahwa indikator kemampuan abstraksi matematis memiliki lima indikator yaitu merepresentasikan kasus ke dalam kaidah dan simbol-simbol matematika, pengidentifikasian dan merumuskan kasus, penyusunan objek matematika lebih lanjut, penyusunan teori matematika terkait teori lain, dan proses mengoperasikan simbol (Kusumawati \& Kurniawan, 2020). Adapun Tata mengelompokkan berdasarkan jenis abstraksi yaitu abstraksi reflektif,empiris, dan teoretis (Yusepa, 2017).

Berdasarkan beberapa pendapat mengenai indikator kemampuan abstraksi matematis serta dengan membatasi pembelajaran matematika pada materi trigonometri, penelitian ini akan menggunakan indikator; (1) kemampuan peserta didik dalam mentransformasi masalah ke dalambentukdan simbol, (2) kemampuan peserta didik dalam membuat persamaan yang setara, (3) kemampuan peserta didik dalam menyatakan hubungan antara konsep bangun datar dengan trigonometri, (4) kemampuan peserta didik dalam menggeneralisasi, dan (5) kemampuan peserta didik membuat persamaan sesuai situasi yang diberikan.

\section{METODE PENELITIAN}

Pengambilan data dilakukan pada bulan Januari 2021. Bentuk penelitian yang digunakan adalah penelitian kualitatif dengan grounded theory karena pada penelitian ini bermaksud untuk mengkaji kemampuan abstraksi matematis peserta didik kelas 12 MAN 1 Tasikmalaya. Teori ini dikembangkan secara induktif serta beriringan dengan data-data yang ada di lapangan (Nisa, 2018). Sehingga pada penelitian ini menemukan teori baru berdasarkan data empirik, bukan menghasilkan teori dari teori yang sudah ada.

Subjek pada penelitian ini adalah peserta didik kelas 12 MAN 1 Tasimalaya sebanyak 5 orang. Sampel diambil dengan cara purposive sampling. Pertimbangan berdasarkan kategori peserta didik dengan level abstraksi matematis level tinggi, abstraksi matematis level sedang, dan abstraksi matematis level rendah. Pengkategorian didasarkan pada nilai rata-rata dan standar deviasi seperti Tabel 1. 
Tabel 1. Level Kemampuan Abstraksi Matematis

\begin{tabular}{cc}
\hline Kemampuan Abstraksi Matematis & Kategori \\
\hline skor $\geq \mu+\frac{1}{2} \sigma$ & Tinggi \\
$\mu-\frac{1}{2} \sigma<$ skor $<\mu+\frac{1}{2} \sigma$ & Sedang \\
skor $\leq \mu-\frac{1}{2} \sigma$ & Rendah \\
\hline
\end{tabular}

Data berupa laporan berbentuk cerita dan penjabaran yang dipecah menjadi 2 bagian yaitu informasi tertulis dan informasi lisan. informasi tertulis diambil dari hasil tes dan informasi lisan diambil dari hasil wawancara tiga peserta didik yang diambil secara acak dari setiap kategori level kemampuan abstraksi matematis. Instrumen divalidasi oleh ahli terlebih dahulu sebelum diberikan kepada peserta didik. Penjabaran informasi meliputi reduksi data, penyajian data, dan verifikasi data.

\section{HASIL PENELITIAN DAN PEMBAHASAN}

Tabel 2 menyajikan banyak peserta didik dengan level kemampuan abstraksi matematis yaitu level tinggi, level sedang, dan level rendah yang ditentukan berdasarkan Tabel 1. Selanjutnya ditentukan 3 subjek, yaitu 1 subjek untuk satu kategori untuk dijabarkan hasil tes dan dilakukan wawancara seperti pada Tabel 3. Apabila terdapat dua atau lebih subjek pada kategori yang sama maka subjek diambil yang melakukan kesalahan terbanyak.

Tabel 2. Jumlah Peserta Didik Berdasarkan Level Kemampuan Abstraksi

Matematis

\begin{tabular}{cccc}
\hline \multicolumn{2}{c}{$\begin{array}{c}\text { Banyak Peserta Didik yang Memiliki } \\
\text { Kemampuan Abstraksi Matematis }\end{array}$} & \multirow{2}{*}{ Jumlah Peserta Didik } \\
\cline { 1 - 2 } Tinggi & Sedang & Rendah & \\
\hline 1 & 3 & 1 & 1 \\
\hline
\end{tabular}


Tabel 3. Hasil Penentuan Subjek

\begin{tabular}{ccc}
\hline No & Subjek & Level Kemampuan Abstraksi Matematis \\
\hline 1 & NE & Tinggi \\
2 & R & Sedang \\
3 & SN & Rendah \\
\hline
\end{tabular}

Tabel 4. Persentase Jumlah Peserta Didik yang Memenuhi Tiap Indikator

Kemampuan Abstraksi Matematis

\begin{tabular}{|c|c|c|c|}
\hline \multirow{3}{*}{ No } & \multirow{3}{*}{ Indikator } & \multicolumn{2}{|c|}{ Jumlah Peserta } \\
\hline & & Didik yang & Persentase \\
\hline & & Memenuhi & \\
\hline \multirow[t]{3}{*}{1} & Kemampuan peserta didik dalam & 4 & $80 \%$ \\
\hline & mentransformasi masalah ke dalam & & \\
\hline & bentuk dan simbol & & \\
\hline \multirow[t]{2}{*}{2} & Kemampuan peserta didik dalam & 4 & $80 \%$ \\
\hline & membuat persamaan yang setara & & \\
\hline \multirow[t]{3}{*}{3} & Kemampuan peserta didik dalam & 3 & $60 \%$ \\
\hline & menyatakan hubungan antara konsep & & \\
\hline & bangun datar dengan trigonometri & & \\
\hline \multirow[t]{2}{*}{4} & Kemampuan peserta didik dalam & 4 & $80 \%$ \\
\hline & menggeneralisasi & & \\
\hline \multirow[t]{2}{*}{5} & Kemampuan peserta didik membuat & 3 & $60 \%$ \\
\hline & persamaan sesuai situasi yang diberikan & & \\
\hline
\end{tabular}

Berdasarkan Tabel 4. Terdapat 3 indikator dengan capaian tertinggi yaitu indikator 1, 2, dan 4 dengan persentase $80 \%$ atau sebanyak 4 orang memiliki kemampuan abstraksi matematis dengan indikator 1, 2, dan 4. Sedangkan indikator yang perlu ditingkatkan yaitu pada indikator 3 dan 5 dengan persentase $60 \%$ atau sebanyak 3 orang memiliki kemampuan abstraksi matematis dengan indikator tersebut.

Untuk mendapatkan informasi yang lebih dalam dilakukan pengkajian terhadap jawaban dan wawancara dengan dilakukannya triangulasi metode untuk 
mendapatkan data valid. Tabel 5, 6 dan 7 menyajikan hasil pengkajian yang dilakukan terhadap subjek NE, R, dan SN.

Tabel 5. Hasil Pengkajian Subjek NE (Kategori Tinggi)

\begin{tabular}{|c|c|c|}
\hline Indikator & Pengkajian Jawaban & Pengkajian Wawancara \\
\hline $\begin{array}{l}\text { Kemampuan peserta } \\
\text { didik dalam } \\
\text { mentransformasi } \\
\text { masalah ke dalam } \\
\text { bentuk dan simbol }\end{array}$ & $\begin{array}{l}\text { Mampu mentransformasi } \\
\text { masalah ke dalam bentuk } \\
\text { dan simbolmatematika } \\
\text { dengan tepat }\end{array}$ & $\begin{array}{l}\text { Subjek NE merasa lebih } \\
\text { mudah mengerjakan } \\
\text { soal apabila } \\
\text { mentransformasi } \\
\text { masalah ke dalam } \\
\text { bentuk dan simbol } \\
\text { matematika terlebih } \\
\text { dahulu }\end{array}$ \\
\hline $\begin{array}{l}\text { Kemampuan peserta } \\
\text { didik dalam membuat } \\
\text { persamaan yang setara }\end{array}$ & $\begin{array}{l}\text { Mampu membuat } \\
\text { persamaan yang setara } \\
\text { dengan tepat }\end{array}$ & $\begin{array}{l}\text { Subjek NE mampu } \\
\text { membuat persamaan } \\
\text { yang setara dengan } \\
\text { tepat }\end{array}$ \\
\hline $\begin{array}{l}\text { Kemampuan peserta } \\
\text { didik dalam } \\
\text { menyatakan hubungan } \\
\text { antara konsep bangun } \\
\text { datar dengan } \\
\text { trigonometri }\end{array}$ & $\begin{array}{l}\text { Mampu menyatakan } \\
\text { hubungan antara konsep } \\
\text { bangun datar dengan } \\
\text { trigonometri dengan tepat }\end{array}$ & $\begin{array}{l}\text { Subjek NE mampu } \\
\text { menyatakan hubungan } \\
\text { antara konsep bangun } \\
\text { datar dengan } \\
\text { trigonometri dengan } \\
\text { tepat }\end{array}$ \\
\hline $\begin{array}{l}\text { Kemampuan peserta } \\
\text { didik dalam } \\
\text { menggeneralisasi }\end{array}$ & $\begin{array}{l}\text { Mampu menggeneralisasi } \\
\text { dengan tepat }\end{array}$ & $\begin{array}{l}\text { Subjek NE mampu } \\
\text { menggeneralisasi } \\
\text { dengan tepat }\end{array}$ \\
\hline $\begin{array}{l}\text { Kemampuan peserta } \\
\text { didik membuat } \\
\text { persamaan sesuai } \\
\text { situasi yang diberikan }\end{array}$ & $\begin{array}{l}\text { Mampu membuat } \\
\text { persamaan sesuai situasi } \\
\text { yang diberikan dengan tepat }\end{array}$ & $\begin{array}{l}\text { Subjek NE mampu } \\
\text { membuat persamaan } \\
\text { sesuai situasi yang } \\
\text { diberikan dengan tepat }\end{array}$ \\
\hline
\end{tabular}

Subyek NE memiliki level kemampuan abstraksi matematis yang tinggi. Subyek NE mampu memenuhi seluruh indikator kemampuan abstraksi matematis. 
Tabel 6. Hasil Pengkajian Subjek R (Kategori Sedang)

\begin{tabular}{|c|c|c|}
\hline Indikator & Pengkajian Jawaban & $\begin{array}{l}\text { Pengkajian } \\
\text { Wawancara }\end{array}$ \\
\hline $\begin{array}{l}\text { Kemampuan peserta } \\
\text { didik dalam } \\
\text { mentransformasi } \\
\text { masalah ke dalam } \\
\text { bentuk dan simbol }\end{array}$ & $\begin{array}{l}\text { Mampu mentransformasi } \\
\text { masalah ke dalam bentuk } \\
\text { dan simbol matematika } \\
\text { dengan tepat }\end{array}$ & $\begin{array}{l}\text { Subjek R merasa lebih } \\
\text { mudah mengerjakan } \\
\text { soal apabila } \\
\text { mentransformasi } \\
\text { masalah ke dalam } \\
\text { bentuk dan simbol } \\
\text { matematika terlebih } \\
\text { dahulu }\end{array}$ \\
\hline $\begin{array}{l}\text { Kemampuan peserta } \\
\text { didik dalam membuat } \\
\text { persamaan yang setara }\end{array}$ & $\begin{array}{l}\text { Mampu membuat } \\
\text { persamaan yang setara } \\
\text { dengan tepat }\end{array}$ & $\begin{array}{l}\text { Subjek R mampu } \\
\text { membuat persamaan } \\
\text { yang setara dengan } \\
\text { tepat }\end{array}$ \\
\hline $\begin{array}{l}\text { Kemampuan peserta } \\
\text { didik dalam } \\
\text { menyatakan hubungan } \\
\text { antara konsep bangun } \\
\text { datar dengan } \\
\text { trigonometri }\end{array}$ & $\begin{array}{l}\text { Tidak memuat hubungan } \\
\text { antara konsep bangun datar } \\
\text { dengan trigonometri }\end{array}$ & $\begin{array}{l}\text { Subjek R tidak } \\
\text { mencantumkan } \\
\text { hubungan antara } \\
\text { konsep bangun datar } \\
\text { dengan trigonometri } \\
\text { karena merasa } \\
\text { kesulitan dan } \\
\text { mencoba meneruskan } \\
\text { mengerjakan soal tes. }\end{array}$ \\
\hline $\begin{array}{l}\text { Kemampuan peserta } \\
\text { didik dalam } \\
\text { menggeneralisasi }\end{array}$ & $\begin{array}{l}\text { Mampu menggeneralisasi } \\
\text { dengan tepat }\end{array}$ & $\begin{array}{l}\text { Subjek R mampu } \\
\text { menggeneralisasi } \\
\text { dengan tepat }\end{array}$ \\
\hline $\begin{array}{l}\text { Kemampuan peserta } \\
\text { didik membuat } \\
\text { persamaan sesuai } \\
\text { situasi yang diberikan }\end{array}$ & $\begin{array}{l}\text { Mampu membuat } \\
\text { persamaan sesuai situasi } \\
\text { yang diberikan dengan } \\
\text { tepat }\end{array}$ & $\begin{array}{l}\text { Subjek R mampu } \\
\text { membuat persamaan } \\
\text { sesuai situasi yang } \\
\text { diberikan dengan tepat }\end{array}$ \\
\hline
\end{tabular}


Subyek R memiliki level kemampuan abstraksi matematis sedang. Subyek R mampu memenuhi 4 indikator yaitu indikator 1, 2, 4, dan 5. Satu indikator yang tidak tercapai yaitu indikator 3 .

Tabel 7. Hasil Pengkajian Subjek SN (Kategori Rendah)

\begin{tabular}{lll}
\hline \multicolumn{1}{c}{ Indikator } & \multicolumn{1}{c}{ Pengkajian Jawaban } & \multicolumn{1}{c}{ Pengkajian Wawancara } \\
\hline Kemampuan peserta & Mentransformasi masalah & Subjek SN merasa \\
didik dalam & ke dalam bentuk dan & kesulitan mentransformasi \\
mentransformasi & simbol matematika & masalah ke dalam bentuk \\
masalah ke dalam & dengan kurang tepat & dan simbol karena \\
bentuk dan simbol & & langsung mengaitkannya \\
& & ke dalam indikator 3 \\
Kemampuan peserta & Mampu membuat & Subjek SN mampu \\
didik dalam membuat & persamaan yang setara & membuat persamaan yang \\
persamaan yang setara & dengan tepat & setara dengan tepat \\
Kemampuan peserta & Menyatakan hubungan & Subjek SN kesulitan dalam \\
didik dalam & antara konsep bangun & mencari hubungan antara \\
menyatakan hubungan & datar dengan trigonometri & konsep bangun datar \\
antara konsep bangun & dengan kurang tepat & dengan trigonometri \\
datar dengan & & \\
trigonometri & & \\
Kemampuan peserta & Menggeneralisasi dengan & Subjek SN kesulitan dalam \\
didik dalam & kurang tepat & menggeneralisasi karena \\
menggeneralisasi & & merasa kesulitan dalam \\
Kemampuan peserta & Mampu membuat & Subjek SN kesulitan \\
didik membuat & persamaan sesuai situasi & membuat persamaan \\
sersamaan sesuai & yang diberikan dengan & sesuai situasi yang \\
\hline & tepat & diberikan karena kesulitan \\
& & dalam indikator 1,3, dan 4 \\
\hline
\end{tabular}


Subyek SN memiliki level kemampuan abstraksi matematis rendah. Subyek SN mampu memenuhi 1 indikator yaitu indikator 2. 4 indikator yang tidak tercapai yaitu indikator $1,3,4$, dan 5 .

Teknik triangulasi dilakukan setelah hasil pengkajian tes tertulis dan wawancara diperoleh pada Tabel 5, 6 dan 7, dapat disimpulkan bahwa:

1) Subjek dengan level kemampuan abstraksi matematis tinggi, semua indikator terpenuhi.

2) Subjek dengan level kemampuan abstraksi matematis sedang, kesulitan pada indikator 3 yaitu mencari hubungan konsep bangun datar dengan trigonometri. Data ini valid setelah dilakukan wawancara.

3) Subjek dengan level kemampuan abstraksi matematis rendah, hanya mampuberdasarkan pengkajian terhadap hasil tes, subyek hanya mampu mencapai indikator 2 yaitu membuat persamaan yang setara. Data ini valid setelah dilakukan wawancara.

Hal ini sejalan dengan beberapa pendapat para ahli yang telah dikemukakan sebelumnya. Semakin tinggi kemampuan abstraksi matematis peserta didik maka akan lebih mampu dalam menyelesaikan masalah-masalah sehari-hari. Sebaliknya semakin rendah kemampuan abstraksi matematis peserta didik maka cenderung kurang mampu dalam menyelesaikan masalah matematis khususnya yang berkaitan dengan kemampuan abstraksi matematis.

\section{SIMPULAN}

Kadar kemampuan abstraksi matematis paling tinggi terdapat di 3 indikator yaitu menetransformasi masalah ke dalam bentuk dan simbol, membuat persamaan yang setara, dan menggeneralisasi yaitu sebesar $80 \%$ atau sebanyak 4 orang. Persentase capaian kemampuan abstraksi matematis terendah terdapat di 2 indikator yaitu menyatakan hubungan antara konsep bangun datar dengan trigonometri, membuat persamaan sesuai situasi yang diberikan yaitu sebesar $60 \%$ atau sebanyak 3 orang. Peserta didik dengan level kemampuan abstraksi matematis tinggi, mampu mencapai semua indikator kemampuan abstraksi matematis. Pada peserta didik dengan level sedang, kesulitan ada pada indikator 
mencari hubungan antara bangun datar dengan trigonometri. Peserta didik dengan level rendah hanya mencapai indikator membuat persamaan yang setara.

\section{DAFTAR PUSTAKA}

Firmansyah, I., \& Ratnaningsih, N. (2019). "Meningkatkan kemampuan penalaran matematik peserta didik melalui pendekatan kontekstual". In Prosiding Seminar Nasional \& Call For Papers (p. 287-295). FKIP Universitas Siliwangi.

Juniarti, A. C., \& Zulkarnaen, R. (2019). Studi kasus kemampuan abstraksi matematis siswa kelas $\mathrm{X}$ pada materi sistem persamaan linier dua variabel (SPLDV). In Prosiding SESIOMADIKA (Vol. 2, No. 1, p. 400-404). Program Studi Pendidikan Matematika, Fakultas Keguruan dan Ilmu Pendidikan, Universitas Singaperbangsa Karawang.

Kusumawati R., \& Kurniawan P. (2020). Pengembangan bahan ajar stuktur aljabar dengan penemuanterbimbing untuk meningkatkan kemampuan abstraksi dan menulis pembuktian matematis. Journal of Medives: Journal of Mathematics Education IKIP Veteran Semarang, 4(1), 197-204. https://doi.org/10.31331/medivesveteran.v4i1.1010

Nisa A. L. (2018). Analisis kemampuan abstraksi matematis siswa dalammenyelesaikan soal pada materi segiempat kelas VII SMP. JPM: Jurnal Pendidikan Matematika, 4(1), 1-8. http://dx.doi.org/10.33474/jpm.v4i1.2610

Nugroho, K. U. Z., dkk. (2021). "Abstraction ability of students about fractions through local cultural approaches". In Proceedings of the International Conference on Educational Sciences and Teacher Profession (ICETeP 2020) (Vol. 532, p. 480-485). Atlantis Press.

Nurhikmayati, I. (2017). Kesulitan siswa berpikir abstrak matematika dalam pembelajaran problem posing berkelompok. KALAMATIKA: Jurnal Pendidikan Matematika, 2(2), 159-176. https://doi.org/10.22236/KALAMATIKA.vol2no2.2017pp159-176

Utami, R. N. F., Nursyifa, Y., \& Ratnaningsih, N. (2021). Proses berpikir metafora dalam memecahkan masalah segitiga dan segiempat ditinjau dari self-confidence siswa. Journal of Authentic Research on Mathematics Education (JARME), 3(1), 6883. https://doi.org/10.37058/jarme.v3i1.2583

Warsito, W., Saleh, H., \& Sukirwan, S. (2020). Interaksi antara pembelajaran dan pengetahuan terhadap abstraksi matematis siswa SMP. Journal of Authentic Research on Mathematics Education (JARME), 2(1), 11-19. https://doi.org/10.37058/jarme.v2i1.1333

Wibowo S. A., Mulyono, M., \& Sumarti, S. (2018). "Penerapan model pembelajaran PBL untuk meningkatkan kemampuan abstraksi matematis dan tanggung jawab siswa kelas XI perhotelan SMKN 6 Semarang”. In PRISMA, Prosiding Seminar Nasional Matematika (Vol. 1, p. 409-415). Universitas Negeri Semarang.

Yusepa B. (2017). Kemampuan abstraksi matematis siswa sekolah menengah pertama (SMP) kelas VIII. Symmetry: Pasundan Journal of Research in Mathematics Learning and Education, 1(1), 54-60. 